\title{
Prevalence of Streptomycin-Resistant Erwinia amylovora in New York Apple Orchards
}

K. A. Tancos, S. Villani, S. Kuehne, and E. Borejsza-Wysocka, Department of Plant Pathology and Plant-Microbe Biology, New York State Agricultural Experiment Station, Cornell University, Geneva NY 14456; D. Breth, Integrated Pest Management, Cornell Cooperative Extension, Albion NY 14411; J. Carol, New York State Integrated Pest Management Program, New York State Agricultural Experiment Station, Cornell University; and H. S. Aldwinckle, and K. D. Cox, Department of Plant Pathology and Plant-Microbe Biology, New York State Agricultural Experiment Station, Cornell University

\begin{abstract}
Tancos, K. A., Villani, S. M., Borejsza-Wysocka, E., Kuehne, S., Breth, D., Aldwinckle, H. S., Carol, J., and Cox, K. D. 2016. Prevalence of streptomycin-resistant Erwinia amylovora in New York apple orchards. Plant Dis. 100:802-809.

Resistance to streptomycin in Erwinia amylovora was first observed in the United States in the 1970s but was not found in New York until 2002, when streptomycin-resistant (SmR) E. amylovora was isolated from orchards in Wayne County. From 2011 to 2014, in total, 591 fire blight samples representing shoot blight, blossom blight, and rootstock blight were collected from 80 apple orchards in New York. From these samples, 1,280 isolates of E. amylovora were obtained and assessed for streptomycin resistance. In all, $34 \mathrm{SmR}$ E. amylovora isolates were obtained from 19 individual commercial orchards. The majority of the resistant isolates were collected from orchards in Wayne County, and the remaining were from other counties in western New York. Of the 34 resistant isolates, 32 contained the streptomycin resistance gene pair strA/strB in the transposon Tn5393 on the nonconjugative plasmid pEA29. This determinant of

streptomycin resistance has only been found in SmR E. amylovora isolates from Michigan and the $\mathrm{SmR}$ E. amylovora isolates discovered in Wayne County, NY in 2002. Currently, our data indicate that SmR E. amylovora is restricted to counties in western New York and is concentrated in the county with the original outbreak. Because the resistance is primarily present on the nonconjugative plasmid, it is possible that $\mathrm{SmR}$ has been present in Wayne County since the introduction in 2002, and has spread within and out of Wayne County to additional commercial growers over the past decade. However, research is still needed to provide in-depth understanding of the origin and spread of the newly discovered SmR E. amylovora to reduce the spread of streptomycin resistance into other apple-growing regions, and address the sustainability of streptomycin use for fire blight management in New York.
\end{abstract}

Fire blight is a devastating disease of apple, pear, and many other rosaceous hosts caused by the bacterium Erwinia amylovora. E. amylovora overwinters in cankers formed during the apple-growing season and initiates infection in the spring, when the orchard temperatures warm and cankers begin to release ooze containing high numbers of bacteria (Beer and Norelli 1977; Vanneste 2000). The bacteria are then spread by insects, wind, and rain to flowers, which are highly susceptible to infection (Wael et al. 1990). Flower stigmas provide a nutrientrich environment in which E. amylovora can colonize and multiply rapidly (Beer and Norelli 1977). Following rain or even dew, these bacteria are washed into the hypanthium and enter natural floral nectaries, which may result in blossom infection producing blackened and necrotic flower clusters (Rosen 1936; Sundin 2014). E. amylovora subsequently spreads internally throughout the vascular tissues, resulting in systemic infections that may kill limbs, the trunk, and the rootstock of the tree. Infection of susceptible rootstocks may result in death of the entire tree (van der Zwet 1969). The loss of entire trees and plantings has a tremendous impact on production. This is especially the case in moderately to highly susceptible apple cultivars, which are widely planted and in increasingly high demand (Bonn and van der Zwet 2000). To complicate matters, modern planting systems in New York are typically composed of tightly spaced ( $>1,000$ trees/acre), small, vigorous trees of highly susceptible scion cultivars (Robinson 2008a,b; Robinson et al. 2013). Because high epiphytic populations of $E$. amylovora may lead to blossom blight, shoot blight, and, potentially, rootstock blight, protecting flowers from infection throughout bloom is essential for managing fire blight in orchards.

Corresponding author: K. D. Cox; E-mail: kdc33@ cornell.edu

Accepted for publication 10 November 2015.

http://dx.doi.org/10.1094/PDIS-09-15-0960-RE

(C) 2016 The American Phytopathological Society
Blossom blight is typically managed by a combination of biological and chemical controls. Biological controls inhibit E. amylovora through antibiosis or competitive inhibition, preventing the buildup of high population levels on the stigma ( $\mathrm{Pal}$ and $\mathrm{Mc}$ Spadden Gardener 2006; Johnson et al. 2009). Although many biological controls are fairly effective in controlling blossom blight in semiarid apple production regions in the western United States, they do not provide effective control of blossom blight in the humid, temperate production regions of the midwestern and northeastern United States (Sundin et al. 2009). Aside from the biological controls, conventional chemical controls for fire blight include copper and antibiotics. Copper is only effective for control of blossom blight when applied prior to infection and can cause deleterious effects to the developing fruit and foliage (Jamar and Lateur 2007; Montag et al. 2006). Hence, copper is usually not applied for blossom blight in orchards producing apple fruit destined for the fresh market. Oxytetracycline can provide effective blossom blight control in semiarid apple production regions such as those in the western United States (Stockwell et al. 2008) but the humid climate of the northeastern United States diminishes the effectiveness of oxytetracycline's bacteriostatic mode of action (van der Zwet et al. 2012). The most effective means of chemical control of blossom blight in the midwestern and northeastern United States is the aminoglycoside antibiotic streptomycin (Cox et al. 2013; Russo et al. 2008; Sundin et al. 2009.). This is primarily due to streptomycin's bactericidal mode of action, its potential for slight curative activity, and the fact that there are no other products offering a similar cost effectiveness (Russo et al. 2008; Sundin et al. 2009; van der Zwet et al. 2012). The aminoglycoside antibiotic kasugamycin was registered for use by the Environmental Protection Agency (EPA) in 2015 (EPA registration number 66330-404) and can provide a similar level of control, but does not have curative activity or the same cost effectiveness as streptomycin (McGhee and Sundin 2011; Yoder et al. 2012).

Because of the aforementioned utility, streptomycin has been used widely in the United States for over 50 years, providing effective and necessary control of E. amylovora outbreaks. However, reports of 
streptomycin resistance have raised concern about the sustainability of this antibiotic for fire blight management. The first reports of streptomycin resistance occurred in California in 1971 followed by Washington and Oregon in 1972 (Coyier and Covey 1975; McManus and Jones 1994; Miller and Schroth 1972). Since these discoveries, streptomycin-resistant (SmR) E. amylovora has become established in apple-growing regions along the western coast of the United States and in certain apple-growing regions of Missouri and Michigan (McManus et al. 2002). SmR isolates of E. amylovora were not observed in New York until 2002 (Beer and Norelli 1976; Russo et al. 2008). In this instance, two SmR isolates of E. amylovora (NY17.1 and NY17.2) were recovered from fire blight outbreaks in two adjacent orchards in Wayne County (Russo et al. 2008). Eradication efforts, which included prompt removal of trees, were put in place in order to contain and destroy $\mathrm{SmR}$ E. amylovora-infected plant materials and prevent spread of these bacteria to other orchards (Russo and Aldwinckle 2009; Russo et al. 2008).

Currently, there are two known determinants of streptomycin resistance in E. amylovora. The first is the presence of a point mutation at codon 43 in the rpsL gene, which codes for the $\mathrm{S} 12$ ribosomal protein (Chiou and Jones 1995a). This single base-pair mutation, causing a substitution of lysine for arginine (K43R), alters the binding site of streptomycin, which would otherwise bind to the $\mathrm{S} 12$ protein and inhibit translation of mRNA to proteins (McManus et al. 2002). In a sensitive strain of E. amylovora, streptomycin binds to the $\mathrm{S} 12$ protein on the ribosome to block protein synthesis, killing the bacterium. This mechanism confers resistance in E. amylovora at streptomycin concentrations up to $2,500 \mu \mathrm{g} / \mathrm{ml}$ (Chiou and Jones 1995a). This mutation is persistent in populations, and is the most common mechanism found in SmR E. amylovora in the western United States (Moller et al. 1981). Strains with this type of resistance are rarely found in apple orchards east of the Mississippi River (McManus et al. 2002).

A second determinant of streptomycin resistance is the gene pair $s t r A / s t r B$. These tandem genes code for aminoglycoside-modifying phosphotransferase enzymes that modify streptomycin, making the antibiotic ineffective within the cell (Chiou and Jones 1995b). These genes are commonly found in many epiphytic bacteria, such as Pseudomonas sp., and reside on conjugative R plasmids (Burr et al. 1988). In E. amylovora, the $s t r A / s t r B$ pair has been found on plasmid RSF1010 (Palmer et al. 1997) and within the transposable element Tn5393 on either a conjugative plasmid pEA34 or a nonconjugative plasmid pEA29 (McGhee et al. 2011; McManus and Jones 1994). The $s t r A / s t r B$ gene pair in Tn5393 on plasmid pEA29, the basis of resistance for the isolates discovered in 2002 in New York, is the most common determinant of resistance in Michigan (Russo et al. 2008; McGhee et al. 2011; McManus and Jones 1994).

Since the discovery and eradication of SmR E. amylovora in 2002, there have been limited investigations regarding these bacteria in New York. Informal surveys from 2004 to 2006 were conducted for SmR E. amylovora in areas of western New York where fire blight developed, but such surveys failed to detect $\operatorname{SmR}$ E. amylovora, leading to the belief that eradication efforts were successful in containing the outbreak in New York. Despite these assurances, apple producers raise concerns about the effectiveness of streptomycin every year, and little is known about the prevalence of SmR E. amylovora in New York beyond the sites of original detection in 2002. Moreover, the genetic determinants responsible for resistance would need to be characterized for any new isolates of SmR E. amylovora recovered from New York apple orchards. In order to address these knowledge gaps, our goals were to examine fire blight outbreaks in New York apple orchards from 2011 to 2014 for the presence $\operatorname{SmR}$ E. amylovora, and to characterize determinants of streptomycin resistance for any $\mathrm{SmR}$ E. amylovora isolates recovered. The resulting information would help New York apple producers better assess the threat of streptomycin resistance development in E. amylovora, and adjust antibiotic use practices for resistance management.

\section{Methods and Materials}

Collection of fire blight samples and isolation of $E$. amylovora. From 2011 to 2014, samples of fire blight were collected from outbreaks at nurseries and production orchards across the apple-growing regions of New York State. Collection efforts took place as a cooperative effort between the New York State Agricultural Experiment Station, Cornell cooperative extension, the Lake Ontario Fruit Program, New York State Integrated Pest Management, and Eastern New York Regional Fruit Program. Sample collection efforts were largely driven by reports from growers and cooperative extensions of instances of fire blight outbreaks within individual orchards of relevance to production sustainability. Samples consisted of blighted blossom clusters, shoot blight of first- and second-year scion, and blighted rootstocks. When fewer than 10 symptomatic trees were present, each tree was sampled. If more than 10 trees were sampled, one sample was collected for every 2 to 5 symptomatic trees. Usually ( $<3 \%$ of all samples), no more than one sample was taken per tree. Isolates representing multiple samples from the same tree were designated by a letter after the sample.

Upon arrival in the New York State Agricultural Experiment Station fruit pathology laboratory, tissue samples were trimmed to obtain sections of symptomatic tissue ( 2 to $3 \mathrm{~cm}$ in length) around the margins of infection. Samples were agitated in a $10 \%$ bleach solution for $15 \mathrm{~min}$ for surface sterilization and subsequently rinsed three times with sterile distilled water. After sterilization, all bark was removed using sterile dissection tools and discarded. The internal tissues were dissected to obtain approximately $1-\mathrm{cm}$ sections of cambium tissue. Sections were immediately plated on Crosse Goodman medium (CG; Crosse and Goodman 1973). If samples were oozing, the samples were also swabbed with a sterile cotton swab, suspended in sterile deionized water, and spread on CG. Plates were incubated at $28^{\circ} \mathrm{C}$ for 2 to 5 days until bacterial growth was visible around the tissue. Resulting bacterial growth was dilution streaked again on CG and grown for 2 days at $28^{\circ} \mathrm{C}$ to obtain single colonies. Single colonies with a cratered appearance on CG characteristic of E. amylovora (Crosse and Goodman 1973) were collected and stored at $-80^{\circ} \mathrm{C}$.

Identification of $\boldsymbol{E}$. amylovora colonies. Polymerase chain reaction (PCR) amplification of plasmid pEA29 was used to confirm the identity for putative E. amylovora isolates with cratered colony appearance on CG. The pEA29 was shown to be a reliable marker for the identification E. amylovora because it is found ubiquitously in isolates collected worldwide; furthermore, laboratory strains cured of the plasmid show reduced virulence and were deemed unlikely to persist in nature (Bereswill et al. 1992; Chiou and Jones 1993; McGhee and Jones 2000). However, it is possible that, if E. amylovora isolates naturally lacking this plasmid exist in New York, these isolates may have been overlooked in this study. PCR amplification of pEA29 was conducted using primers previously developed by McManus and Jones (1995) (Table 1). PCR assays were performed in $25-\mu \mathrm{l}$ reaction volumes and consisted of $12.3 \mu \mathrm{l}$ of $\mathrm{H}_{2} \mathrm{O}, 5 \mu \mathrm{l}$ of $5 \times$ Green GoTaq Flexi Buffer (Promega Corp., Madison, WI), $1 \mu 1$ each of forward and reverse primers (AJ75 and AJ76), $0.5 \mu \mathrm{l}$ of $10 \mathrm{mM}$ dNTP mix (Promega Corp.), $2.5 \mu \mathrm{l}$ of $25 \mathrm{mM} \mathrm{MgCl}_{2}$ (Promega Corp.), $0.2 \mu 1$ of GoTaq G2 Flexi DNA Polymerase (Promega Corp.), and $2.5 \mu \mathrm{l}$ of bacterial suspension sample. Cycling parameters were $5 \mathrm{~min}$ at $94^{\circ} \mathrm{C}$; followed by 35 cycles of $94^{\circ} \mathrm{C}$ for $30 \mathrm{~s}$, annealing at $52^{\circ} \mathrm{C}$ for $30 \mathrm{~s}$, and $72^{\circ} \mathrm{C}$ for $30 \mathrm{~s}$; followed by a final extension at $72^{\circ} \mathrm{C}$ for $7 \mathrm{~min}$. PCR products were separated using gel electrophoresis with $1 \%$ agarose gels in $1 \times$ Tris-acetate-EDTA buffer (44.5 mM Tris-acetate and $1 \mathrm{mM}$ EDTA, $\mathrm{pH} \mathrm{8.0)}$ ) at $90 \mathrm{~V}$ for $60 \mathrm{~min}$. The resulting amplified region was sequenced for a subset of colonies for confirmation of the presence of pEA29. PCR products were purified for sequencing using a Zymo DNA Clean \& Concentrator kit (Zymo Research, Irvine, CA). Purified products were sequenced at the Cornell Biotechnical Resource center in Ithaca, NY using an ABI 3730xl capillary electrophoresis instrument (Applied Biosystems, Waltham, MA).

Streptomycin resistance screening of $E$. amylovora isolates. Isolates positively identified as E. amylovora were assessed for streptomycin resistance in vitro. Initially, single colonies of the isolates were grown in $1 \mathrm{ml}$ of Luria-Bertani (LB) broth (Bertani 1952) at $28^{\circ} \mathrm{C}$ for $24 \mathrm{~h}$. Following incubation, $100 \mu \mathrm{l}$ of the solution was spread on LB media and allowed to dry. Autoclaved filter paper discs were soaked in streptomycin sulfate (Sigma-Aldrich, St. Louis) at 0, 
100 , and $2,500 \mu \mathrm{g} / \mathrm{ml}$ and placed on the $\mathrm{LB}$ containing the isolate lawns. Plates were incubated at $28^{\circ} \mathrm{C}$ for $48 \mathrm{~h}$, and streptomycin resistance was evaluated by observing the presence or absence of a zone of inhibition around the streptomycin discs. The lack of a zone of inhibition at each concentration confirmed resistance at varying concentrations of streptomycin sulfate, and isolates with resistance phenotypes were retested to confirm resistance.

Isolates of E. amylovora with an SmR phenotype and the streptomycin sensitive (SmS) isolate Ea273 (Norelli et al. 1984), used as a positive control, were assessed for pathogenicity using immature pear fruit as previously described (Billing et al. 1960). Immature 'Bartlett' pear fruit (10 to $20 \mathrm{~mm}$ in diameter) were cut into $15-\mathrm{mm}$ cross sections and wounded with sterile toothpicks that were touched to individual isolate colonies. Inoculated pear fruit cross sections were incubated on moist filter paper in petri dishes at $28^{\circ} \mathrm{C}$ for 48 to $96 \mathrm{~h}$. Inoculated wound sites were observed for the presence of necrosis and bacterial ooze.

Identification of the $\operatorname{str} A / \mathrm{str} B$ gene pair in $\operatorname{SmR} E$. amylovora isolates. All $\mathrm{SmR}$ isolates and the $\mathrm{SmS}$ isolate Ea273 (negative control) were tested for the presence of the $\operatorname{strA} / \mathrm{str} B$ gene pair using primers previously developed by Russo et al. (2008) (Table 1). PCR assays were performed in $25-\mu 1$ reaction volumes and consisted of $12.3 \mu \mathrm{l}$ of $\mathrm{H}_{2} \mathrm{O}, 5 \mu \mathrm{l} 5 \times$ Green GoTaq Flexi Buffer (Promega Corp.), $1 \mu \mathrm{l}$ of forward and reverse primer (strA406-F and strA406-R for strA and strB403-F and strB403-R for $s t r B$ ), $0.5 \mu l$ of $10 \mathrm{mM}$ dNTP mix (Promega Corp.), $2.5 \mu \mathrm{l}$ of $25 \mathrm{mM} \mathrm{MgCl}_{2}$ (Promega Corp.), $0.2 \mu$ l of GoTaq G2 Flexi DNA Polymerase (Promega Corp.), and $2.5 \mu \mathrm{l}$ of bacterial suspension sample, resulting in a $50-\mu \mathrm{l}$ reaction. Cycling parameters were $5 \mathrm{~min}$ at $94^{\circ} \mathrm{C}$; followed by 35 cycles of $94^{\circ} \mathrm{C}$ for $30 \mathrm{~s}$, annealing for $30 \mathrm{~s}\left(56^{\circ} \mathrm{C}\right.$ for $s t r A$ primers and $53^{\circ} \mathrm{C}$ for $s t r B$ ), and $72^{\circ} \mathrm{C}$ for $30 \mathrm{~s}$; followed by a final extension at $72{ }^{\circ} \mathrm{C}$ for $7 \mathrm{~min}$. PCR products were visualized using gel electrophoresis on a $1 \%$ agarose gel. For a subset of isolates, PCR products were purified for sequencing using a Zymo DNA Clean $\&$ Concentrator kit (Zymo Research). Purified products were then sequenced at the Cornell Biotechnical Resource center in Ithaca, NY using an ABI 3730xl capillary sequencer (Applied Biosystems).

Determination of the Tn5393 insertion site on pEA29 pair SmR E. amylovora isolates. All SmR isolates with the $s t r A / s t r B$ gene pair and two SmR isolates (DM1 and MI5-1, positive controls; McGhee et al. 2011) were tested for the presence and insertion of Tn5393 in pEA29 using primers Tn5393E and AJ1717 (pEA29 position 1,515) and AJ507 and AJ339 (pEA29 position 17,527), as described by McGhee et al. (2011). PCR assays were performed in $25-\mu \mathrm{l}$ reaction volumes and consisted of $12.3 \mu \mathrm{l}$ of $\mathrm{H}_{2} \mathrm{O}, 5 \mu \mathrm{l}$ of $5 \times$ Green GoTaq Flexi Buffer (Promega Corp.), $1 \mu$ of forward and reverse primer, $0.5 \mu \mathrm{l}$ of $10 \mathrm{mM}$ dNTP mix (Promega Corp.), $2.5 \mu \mathrm{l}$ of $25 \mathrm{mM} \mathrm{MgCl}_{2}$ (Promega Corp.), $0.2 \mu \mathrm{l}$ of GoTaq G2 Flexi DNA Polymerase (Promega Corp.), and $2.5 \mu \mathrm{l}$ of bacterial suspension sample, resulting in a $50-\mu 1$ reaction. Cycling parameters were identical to those reported for the two sets of primer pairs in McGhee et al. (2011). PCR products were visualized using gel electrophoresis on a $2 \%$ agarose gel. For a subset of isolates, PCR products were purified for sequencing using a Zymo DNA Clean \& Concentrator kit (Zymo Research).
S12 ribosomal protein $r p s L$ gene identification and sequencing in SmR E. amylovora isolates. Isolates confirmed to have a streptomycin resistance phenotype that would allow them to grow in the presence of streptomycin sulfate at $2,500 \mu \mathrm{g} / \mathrm{ml}$ were examined for the presence of mutations at codon 43 in the rpsL gene. Using primers previously developed by Russo et al. (2008) (Table 1), a portion of the rps $L$ gene containing codon 43 was amplified and sequenced. PCR assays consisted of $24.6 \mu \mathrm{l}$ of $\mathrm{H}_{2} \mathrm{O}, 5 \mu \mathrm{l}$ of $5 \times$ Green GoTaq Flexi Buffer (Promega Corp.), $2.0 \mu \mathrm{l}$ each of forward and reverse primer (rpsL212-F and rpsL212-R), $1.0 \mu \mathrm{l}$ of $10 \mathrm{mM}$ dNTP mix (Promega Corp.), $5.0 \mu \mathrm{l}$ of $25 \mathrm{mM} \mathrm{MgCl}$ (Promega Corp.), $0.4 \mu \mathrm{l}$ of GoTaq G2 Flexi DNA Polymerase (Promega Corp.), and $5.0 \mu \mathrm{l}$ of bacterial suspension sample resulting in a $50-\mu 1$ reaction. Cycling parameters were $5 \mathrm{~min}$ at $94^{\circ} \mathrm{C}$; followed by 35 cycles of $94^{\circ} \mathrm{C}$ for 30 $\mathrm{s}$, annealing at $53^{\circ} \mathrm{C}$ for $30 \mathrm{~s}$, and $72^{\circ} \mathrm{C}$ for $30 \mathrm{~s}$; followed by a final extension at $72^{\circ} \mathrm{C}$ for $7 \mathrm{~min}$. PCR products were purified for sequencing using a Zymo DNA Clean \& Concentrator kit (Zymo Research). Purified products were sequenced at the Cornell Biotechnical Resource center in Ithaca, NY using an ABI 3730xl capillary electrophoresis instrument (Applied Biosystems).

\section{Results}

Collection of fire blight samples and isolation of E. amylovora. From 2011 to 2014, samples were collected from a total of 80 commercial orchards with fire blight outbreaks. The majority of the samples were from orchards in Wayne, Monroe, Niagara, Ontario, Orleans, and Tompkins Counties in western New York. By comparison, only 19 of the 591 samples were from Albany, Clinton, Orange, Suffolk, and Ulster Counties in eastern New York. Of the 591 samples collected, 97 were blighted blossoms, 415 were shoot blight of first- or second-year scions, and 74 were blighted rootstocks. In addition, there were five samples collected from the coleopteran Xylosandrus germanus or its galleries that appeared to be oozing with fire blight. Across all years, samples were predominantly from 'Gala', 'Gingergold', 'Honeycrisp', 'SnapDragon', and 'RubyFrost' apple. From the samples, 1,384 bacterial isolates were obtained and 1,280 were confirmed to be E. amylovora. Single colonies of isolates produced the characteristic cratered appearance on CG and, when PCR was performed using primers AJ75 and AJ76, all isolates produced an 840-bp band, indicative of the presence of the ubiquitous, nonconjugative plasmid pEA29.

Streptomycin resistance screening and pathogenicity of $E$. amylovora isolates. Of the 1,280 isolates, 34 displayed an $\mathrm{SmR}$ phenotype on CG, in that a zone of inhibition failed to develop around filter papers discs with streptomycin concentrations of $100 \mu \mathrm{g} / \mathrm{ml}$. For 2 of the 34 isolates (306b and 189a), a zone of inhibition failed to develop around filter papers discs with streptomycin concentrations of 2,500 $\mu \mathrm{g} / \mathrm{ml}$ (Table 2). All $34 \mathrm{SmR}$ isolates of E. amylovora isolates and Ea273 were found to produce necrotic lesions and bacterial ooze within 48 to $96 \mathrm{~h}$ on immature pear fruit confirming pathogenicity (Table 2).

Of the $34 \mathrm{SmR}$ isolates of E. amylovora, 20 were recovered from orchards in Wayne County and 5 were from orchards in Ontario County (Tables 2 and 3 ). The remaining isolates were recovered from

Table 1. Primers used in this study to confirm the identity of Erwinia amylovora isolates, and to determine the presence of the gene pair $s t r A / s t r B$ and amplify the rps $L$ gene for sequencing

\begin{tabular}{|c|c|c|c|}
\hline Target $^{\mathbf{a}}$ & Primer designation & Sequence $\left(5^{\prime}-3^{\prime}\right)^{b}$ & Source \\
\hline \multirow[t]{2}{*}{ pEA29 } & AJ75 & CGTATTCACGGCTTCGCAGAT & McManus and Jones 1995 \\
\hline & AJ76 & AACCGCCAGGATAGTCGCATA & $\ldots$ \\
\hline \multirow[t]{2}{*}{ strA } & strA406-F & TGACTGGTTGCCTGTCAGAG & Russo et al. 2008 \\
\hline & strA406-R & CGGTAAGAAGTCGGGATTGA & $\ldots$ \\
\hline \multirow[t]{2}{*}{$\operatorname{str} B$} & strB403-F & ATCGCTTTGCAGCTTTGTTT & Russo et al. 2008 \\
\hline & strB403-R & CGTTGCTCCTCTTCTCCATC & $\ldots$ \\
\hline \multirow[t]{2}{*}{$r p s L$} & rpsL212-F & CGTACGCAAAGTTGCAAAAA & Russo et al. 2008 \\
\hline & rpsL212-R & GGATCAGGATCACGGAGTGT & $\ldots$ \\
\hline
\end{tabular}

\footnotetext{
${ }^{\text {a }}$ Plasmid or gene target amplified by the PCR primer set.

b Primer sequence in the $5^{\prime}$ to $3^{\prime}$ direction for the forward and reverse primer.
} 
orchards in Monroe, Orleans, Tompkins, and Niagara Counties in western New York (Fig. 1). These isolates were recovered from 19 individual orchards in which $\mathrm{SmR} E$. amylovora was isolated from 4 to $100 \%$ of samples (Tables 2 and 3). Isolates of SmR E. amylovora were recovered from 20 cultivars of apple, with three or more SmR isolates recovered from 'Idared', RubyFrost, and 'McIntosh' apple. Nearly all of the isolates $(n=28)$ were obtained from blighted shoots that developed in the current year's scion tissue (Table 2). Three isolates were obtained from blossom clusters, two from rootstock blight samples, and one from the coleopteran $X$. germanus.

Identification of the $s t r A / s t r B$ gene pair and Tn5393 insertion site on pEA29 in SmR E. amylovora isolates. Amplification of the Tn5393 region containing the $\operatorname{str} A / \operatorname{str} B$ gene pair revealed the presence of a 406- and 403-bp band in 32 of the SmR isolates of E. amylovora. These bands were not present for $\mathrm{SmS}$ isolate Ea273 and the two SmR isolates 306b and 189a, which grew in the presence of streptomycin at $2,500 \mu \mathrm{g} / \mathrm{ml}$. Sequencing of these regions confirmed the identity of the 406- and 403-bp bands (GenBank accession numbers KT899306 and KT899307) to be the strA and $s t r B$ genes previously described for $\mathrm{SmR}$ isolates of $E$. amylovora (Russo et al. 2008). The Tn5393 insertion site for all 32 isolates occurred at position 17,527 on pEA29, as shown by the presence of an expected 396-bp band (Fig. 2).

S12 ribosomal protein $r p s L$ gene identification and sequencing in SmR E. amylovora isolates. Amplification of the region containing codon 43 of the $S 12$ ribosomal protein yielded a 212-bp band for all $34 \mathrm{SmR}$ isolates of E. amylovora and Ea273, the SmS control. Sequencing of the 212-bp band confirmed the identity of the 212-bp region to be a portion of the rpsL gene of E. amylovora. Sequences of each resistant isolate were compared with the sequence of the sensitive isolate Ea273 (GenBank accession number KT899305). Two isolates, 306b (GenBank accession number KT899304) and 189a, were found to have a point mutation at codon 43 (Table 2). In both isolates, this mutation resulted in an amino acid change from lysine to arginine (K43R). The remaining 32 isolates and the $\mathrm{SmS}$ isolate Ea273 did not have a mutation present in this region.

\section{Discussion}

In total, $34 \mathrm{SmR}$ isolates of E. amylovora were found in 19 individual orchards across six counties in western New York (Tables 2 and 3). Although 19 samples were collected from orchards in five counties in eastern New York, SmR E. amylovora was not found

Table 2. Characteristics of streptomycin-resistant (SmR) Erwinia amylovora isolates collected in from apple orchards in New York from 2011 to 2014

\begin{tabular}{|c|c|c|c|c|c|c|c|c|c|}
\hline Year, isolate & Orchard $^{\mathbf{a}}$ & County & Cultivar $^{\mathbf{b}}$ & Tissue $^{\mathrm{c}}$ & $\operatorname{SmR}(\%)^{d}$ & pEA29e & Pathogenic ${ }^{\mathrm{f}}$ & $\operatorname{str} A /$ str $^{\mathrm{g}}$ & $r p s L^{\mathrm{h}}$ \\
\hline \multicolumn{10}{|l|}{2011} \\
\hline 161 & W1 & Wayne & 'Idared' & Shoot & 12 & + & + & + & - \\
\hline 162 & W1 & Wayne & 'Rome' & Shoot & 12 & + & + & + & - \\
\hline 173 & W1 & Wayne & SnapDragon & Shoot & 12 & + & + & + & - \\
\hline 174 & W1 & Wayne & 'RubyFrost' & Shoot & 12 & + & + & + & - \\
\hline 175 & W1 & Wayne & 'McIntosh' & Shoot & 12 & + & + & + & - \\
\hline 176 & W1 & Wayne & 'Red Delicious' & Shoot & 12 & + & + & + & - \\
\hline 177 & $\mathrm{O} 1$ & Ontario & 'Idared' & Shoot & 50 & + & + & + & - \\
\hline 178 & M1 & Monroe & 'Idared' & Shoot & 33 & + & + & + & - \\
\hline 179 & W2 & Wayne & 'Rhode Island Greening' & Shoot & 100 & + & + & + & - \\
\hline \multicolumn{10}{|l|}{2012} \\
\hline 316 & M2 & Monroe & 'RubyFrost' & Shoot & 17 & + & + & + & - \\
\hline 301 & N1 & Niagara & 'SweeTango' & Shoot & 50 & + & + & + & - \\
\hline 230 & $\mathrm{O} 2$ & Ontario & 'Idared' & Shoot & 40 & + & + & + & - \\
\hline 313 & $\mathrm{O} 2$ & Ontario & 'Twenty ounce' & Rootstock & 40 & + & + & + & - \\
\hline $306 a$ & $\mathrm{O} 3$ & Ontario & 'Lady' & Shoot & 25 & + & + & + & - \\
\hline $306 b$ & $\mathrm{O} 3$ & Ontario & 'Lady' & Shoot & 25 & + & + & - & K43R \\
\hline 249 & Or1 & Orleans & 'Aztec Fuji' & Blossom & 15 & + & + & + & - \\
\hline 278 & Or1 & Orleans & 'Cameo' & Shoot & 15 & + & + & + & - \\
\hline 254 & W2 & Wayne & 'M.26 RS' & Shoot & 100 & + & + & + & - \\
\hline 292 & W5 & Wayne & 'Idared' & Shoot & 20 & + & + & + & - \\
\hline 189 & W4 & Wayne & Gingergold & Shoot & 25 & + & + & + & - \\
\hline $189 \mathrm{a}$ & W4 & Wayne & Gingergold & Shoot & 25 & + & + & - & K43R \\
\hline $189 \mathrm{~b}$ & W4 & Wayne & Gingergold & Shoot & 25 & + & + & + & - \\
\hline $2992 d$ & W3 & Wayne & 'RubyFrost' & Shoot & 45 & + & + & + & - \\
\hline $3002 d$ & W3 & Wayne & Gala & Shoot & 45 & + & + & + & - \\
\hline $3002 \mathrm{e}$ & W3 & Wayne & Gala & Shoot & 45 & + & + & + & - \\
\hline \multicolumn{10}{|l|}{2013} \\
\hline 465 & M3 & Monroe & 'Royal Court' & Blossom & 4 & + & + & + & - \\
\hline 321 & Or2 & Orleans & M.9 & Rootstock & 17 & + & + & + & - \\
\hline 436 & $\mathrm{~T} 1$ & Tompkins & 'McIntosh' & Blossom & 22 & + & + & + & - \\
\hline 439 & $\mathrm{~T} 1$ & Tompkins & 'McIntosh' & Shoot & 22 & + & + & + & - \\
\hline 330 & W7 & Wayne & 'Jonagold' & Shoot & 8 & + & + & + & - \\
\hline 333 & W7 & Wayne & 'Jonagold' & Shoot & 8 & + & + & + & - \\
\hline 345 & W8 & Wayne & 'Pink Lady' & Shoot & 9 & + & + & + & - \\
\hline 508 & W6 & Wayne & 'Idared' & Shoot & 17 & + & + & + & - \\
\hline 374 & W9 & Wayne & 'Macoun' & Xylosandrus germanus & 5 & + & + & + & - \\
\hline
\end{tabular}

a Orchard designation, with the letter indicating the county from which the orchard was planted and the number indicating a specific grower operation.

${ }^{\mathrm{b}}$ Malus $\times$ domestica cultivar scion or rootstock from which the tissue sample was collected.

c Type of apple tissue from which the isolate was collected.

d Percentage of samples from which SmR E. amylovora was isolated in each orchard.

e Presence (+) or absence (-) of the nonconjugative plasmid pEA29 ubiquitous in E. amylovora.

${ }^{\mathrm{f}}$ Isolate pathogenicity on immature pear fruit: $(+)$ isolate produced necrosis and ooze or $(-)$ isolate produced neither ooze nor necrosis

g Presence (+) or absence (-) of the $\operatorname{str} A /$ strB gene pair responsible for conferring resistance to streptomycin.

${ }^{\mathrm{h}}$ Presence (K43R) or absence (-) of the K43R mutation in the rpsL gene. 
in the eastern apple production regions of the state. Given that the use of streptomycin for fire blight management practices is fairly consistent throughout the state (K. Cox, unpublished data), the absence of $\mathrm{SmR}$ in eastern New York may suggest that the emergence of streptomycin resistance in western New York after 2002 may be due to local transport of asymptomatic propagative materials or localized spread of isolates in regionalized storms over the last decade. However, such patterns of emergence cannot be used as evidence or an explanation for the spread SmR E. amylovora.

Although the fire blight collection taskforce made efforts to scout all of the major commercial production operations throughout the state, by no means do our efforts represent a structured, systematic sampling survey effort. Of the fire blight outbreaks that were observed by the survey team, they primarily were found on blocks planted to RubyFrost, Gala, Gingergold, SnapDragon, and Honeycrisp but

Table 3. Summary of survey information for orchards where streptomycinresistant (SmR) Erwinia amylovora was detected

\begin{tabular}{|c|c|c|c|c|}
\hline Orchard $^{\mathrm{a}}$ & Year & County, city & $\begin{array}{c}\text { Total } \\
\text { isolates }\end{array}$ & SmR isolates ${ }^{\mathrm{c}}$ \\
\hline \multirow[t]{4}{*}{ W1 } & 2011 & Wayne, Huron & 41 & 6 \\
\hline & 2012 & Wayne, Huron & 1 & 1 \\
\hline & 2013 & Wayne, Huron & No fire blight & $\ldots$ \\
\hline & 2014 & Wayne, Huron & 10 & 0 \\
\hline \multirow[t]{2}{*}{$\mathrm{O} 1$} & 2011 & Ontario, Phelps & 1 & 1 \\
\hline & 2012-14 & Ontario, Phelps & No fire blight & $\ldots$ \\
\hline \multirow[t]{2}{*}{ M1 } & 2011 & Monroe, Webster & 2 & 1 \\
\hline & $2012-14$ & Monroe, Webster & No fire blight & $\ldots$ \\
\hline \multirow[t]{2}{*}{ W2 } & 2011 & Wayne, Sodus & 3 & 1 \\
\hline & 2012-14 & Wayne, Sodus & No fire blight & $\ldots$ \\
\hline \multirow[t]{3}{*}{ M2 } & 2012 & Monroe, Brockport & 6 & 1 \\
\hline & 2013 & Monroe, Brockport & 13 & 0 \\
\hline & 2014 & Monroe, Brockport & No fire blight & $\ldots$ \\
\hline \multirow[t]{3}{*}{ N1 } & 2012 & Niagara, Appleton & 2 & 1 \\
\hline & 2013 & Niagara, Appleton & No fire blight & $\ldots$ \\
\hline & 2014 & Niagara, Appleton & 30 & 0 \\
\hline \multirow[t]{2}{*}{$\mathrm{O} 2$} & 2012 & Ontario, Phelps & 7 & 2 \\
\hline & 2013-14 & Ontario, Phelps & No fire blight & $\ldots$ \\
\hline \multirow[t]{2}{*}{$\mathrm{O} 3$} & 2012 & Ontario, Geneva & 7 & 2 \\
\hline & 2013-14 & Ontario, Geneva & No fire blight & $\ldots$ \\
\hline \multirow[t]{3}{*}{ Or1 } & 2012 & Orleans, Kendall & 16 & 2 \\
\hline & 2013 & Orleans, Kendall & No fire blight & $\ldots$ \\
\hline & 2014 & Orleans, Kendall & 5 & 0 \\
\hline \multirow[t]{3}{*}{ W5 } & 2012 & Wayne, Macedon & 6 & 1 \\
\hline & 2013 & Wayne, Macedon & 3 & 0 \\
\hline & 2014 & Wayne, Macedon & 35 & 0 \\
\hline \multirow[t]{3}{*}{ W4 } & 2012 & Wayne, Wolcott & 4 & 3 \\
\hline & 2013 & Wayne, Wolcott & No fire blight & $\ldots$ \\
\hline & 2014 & Wayne, Wolcott & 80 & 0 \\
\hline \multirow[t]{2}{*}{ W3 } & 2012 & Wayne, Williamson & 17 & 3 \\
\hline & 2013-14 & Wayne, Williamson & No fire blight & $\ldots$ \\
\hline \multirow[t]{2}{*}{ M3 } & 2013 & Monroe, Hilton & 30 & 1 \\
\hline & 2014 & Monroe, Hilton & 10 & 0 \\
\hline \multirow[t]{2}{*}{ Or2 } & 2013 & Orleans, Medina & 5 & 1 \\
\hline & 2014 & Orleans, Medina & 25 & 0 \\
\hline \multirow[t]{2}{*}{$\mathrm{T} 1$} & 2013 & Tompkins, Lansing & 7 & 2 \\
\hline & 2014 & Tompkins, Lansing & No fire blight & $\ldots$ \\
\hline \multirow[t]{2}{*}{ W7 } & 2013 & Wayne, Wolcott & 23 & 2 \\
\hline & 2014 & Wayne, Wolcott & No fire blight & $\ldots$ \\
\hline \multirow[t]{2}{*}{ W8 } & 2013 & Wayne, Sodus & 21 & 1 \\
\hline & 2014 & Wayne, Sodus & No fire blight & $\ldots$ \\
\hline \multirow[t]{2}{*}{ W6 } & 2013 & Wayne, Williamson & 5 & 1 \\
\hline & 2014 & Wayne, Williamson & No fire blight & $\ldots$ \\
\hline \multirow[t]{2}{*}{ W9 } & 2013 & Wayne, Sodus & 24 & 1 \\
\hline & 2104 & Wayne, Sodus & 13 & 0 \\
\hline
\end{tabular}

a Orchard designation with the letter indicating the county from which the orchard was planted and the number indicating a specific grower operation.

b Total number of E. amylovora isolates. "No fire blight" indicates that an orchard did not develop fire blight to sample.

c Number of SmR E. amylovora isolates collected from symptomatic trees for each year of the survey. isolates of SmR E. amylovora were rarely found on these cultivars. It may be that RubyFrost, Gala, Gingergold, SnapDragon, and Honeycrisp apple are rather susceptible to fire blight and growers with these cultivars should take additional care with fire blight management practices. It should be noted that all plantings of RubyFrost and SnapDragon were no more than 1 year old. Hence, apparent sensitivity of RubyFrost and SnapDragon may have been masked by overly vigorous production in the establishment years.

Aside from cultivar trends, the majority of the SmR E. amylovora isolates were recovered shoot blight samples. Shoot blight samples made up the majority of fire blight samples observed and collected by the survey team because blossom blight and rootstock blight were rarely observed by comparison. Shoot blight samples were all collected in late June through July (data not shown), when most of the streptomycin use had ceased. Shoot blight is typically initiated either by internal migration of E. amylovora to the growing shoot tips or by trauma to growing shoots, which become infected by $E$. amylovora spread from oozing cankers and infected flower clusters (van der Zwet et al. 2012). Hence, SmR E. amylovora isolates collected from shoot blight samples may not have emerged from local streptomycin control failures or streptomycin overuse during bloom. Alternatively, $\mathrm{SmR}$ E. amylovora found in shoot blight samples may have resulted from the limited streptomycin applications often made to protect against fire blight during storms that occur within the period of shoot elongation. Although data from the current study cannot prove that applications of streptomycin for shoot blight management lead to the development of streptomycin resistance, it cannot be discounted because several producers with $\mathrm{SmR}$ E. amylovora isolated from blighted shoots often reported using streptomycin after bloom for shoot blight management.

Of the SmR E. amylovora isolates recovered, a total of 32 contained the $s t r A / s t r B$ gene pair located on the Tn5393 transposon on pEA29. This $s t r A / s t r B$ gene pair itself has been shown to confer a streptomycin resistance in several bacterial species commonly found on the surfaces of apple fruit (Burr et al. 1988, 1993). The $\operatorname{strA} / \operatorname{str} B$ gene pair has been reported to confer resistance to $\mathrm{SmR}$ isolates of E. amylovora from Michigan and California at concentrations of 100 to $200 \mu \mathrm{g} / \mathrm{ml}$ in vitro (Chiou and Jones 1991; Chiou and Jones 1993; Palmer et al. 1997; Russo et al. 2008;). In agreement with the previous reports, all $34 \mathrm{SmR}$ isolates displayed resistance to streptomycin at a minimum of $100 \mu \mathrm{g} / \mathrm{ml}$ in vitro. This level of resistance is particularly relevant for the management of fire blight given that agricultural applications of streptomycin are applied at a target rate of $100 \mu \mathrm{g} / \mathrm{ml}(100 \mathrm{ppm})$. Hence, any grower operations with these isolates would not be able to fully manage blossom blight using applications of streptomycin and would need to rely on kasugamycin, copper, or other biological controls.

Aside from the implications regarding the level of resistance, the presence of the $\operatorname{strA} / \mathrm{str} B$ gene pair in the Tn5393 transposon in E. amylovora may shed some light on the origin of streptomycin resistance. This gene pair transposon combination has only been found on conjugative (pEA34) and nonconjugative (pEA29) plasmids in isolates from Michigan and New York (Chiou and Jones 1993; McManus and Jones 1994; Russo et al. 2008). The $\operatorname{strA} /$ strB gene pair has been shown to confer resistance in E. amylovora in California but the gene pair was on plasmid RSF1010 (Palmer et al. 1997). In the current study, all 32 isolates had the $\operatorname{str} A / s t r B$ gene pair in Tn5393 on pEA29. The isolates also belong to the lineage from Michigan with the 17,527-nucleotide position insertion site for Tn5393 on pEA29 (McGhee et al. 2011). Because the gene pair transposon combination resides on a plasmid that has shown to be nontransmissable between strains of E. amylovora, the isolates from the current study must be physically dispersed to new locations (McGhee and Jones 2000). Hence, these $32 \mathrm{SmR}$ E. amylovora isolates are likely to have been transported to or spread among locations in western New York instead of local emergence due to the ingress of resistance plasmids from local epiphytic bacterial species with streptomycin resistance. Local physical distribution of isolates would further explain the lack of SmR E. amylovora in apple operations in eastern New York. Indeed, half of the SmR E. amylovora isolates 
with the $s t r A / s t r B$ gene pair were obtained from orchards in Wayne County, within $160 \mathrm{~km}$ of the location where the SmR E. amylovora isolates were discovered in 2002 (Russo et al. 2008). Planting material is rarely shared outside the neighboring production operations and statewide dispersal by storms is unlikely. The localization of SmR isolates in western New York raises questions about the success of the eradication efforts in 2002 and the possibility of additional acquisitions of trees from southwest Michigan in 2002, as described by

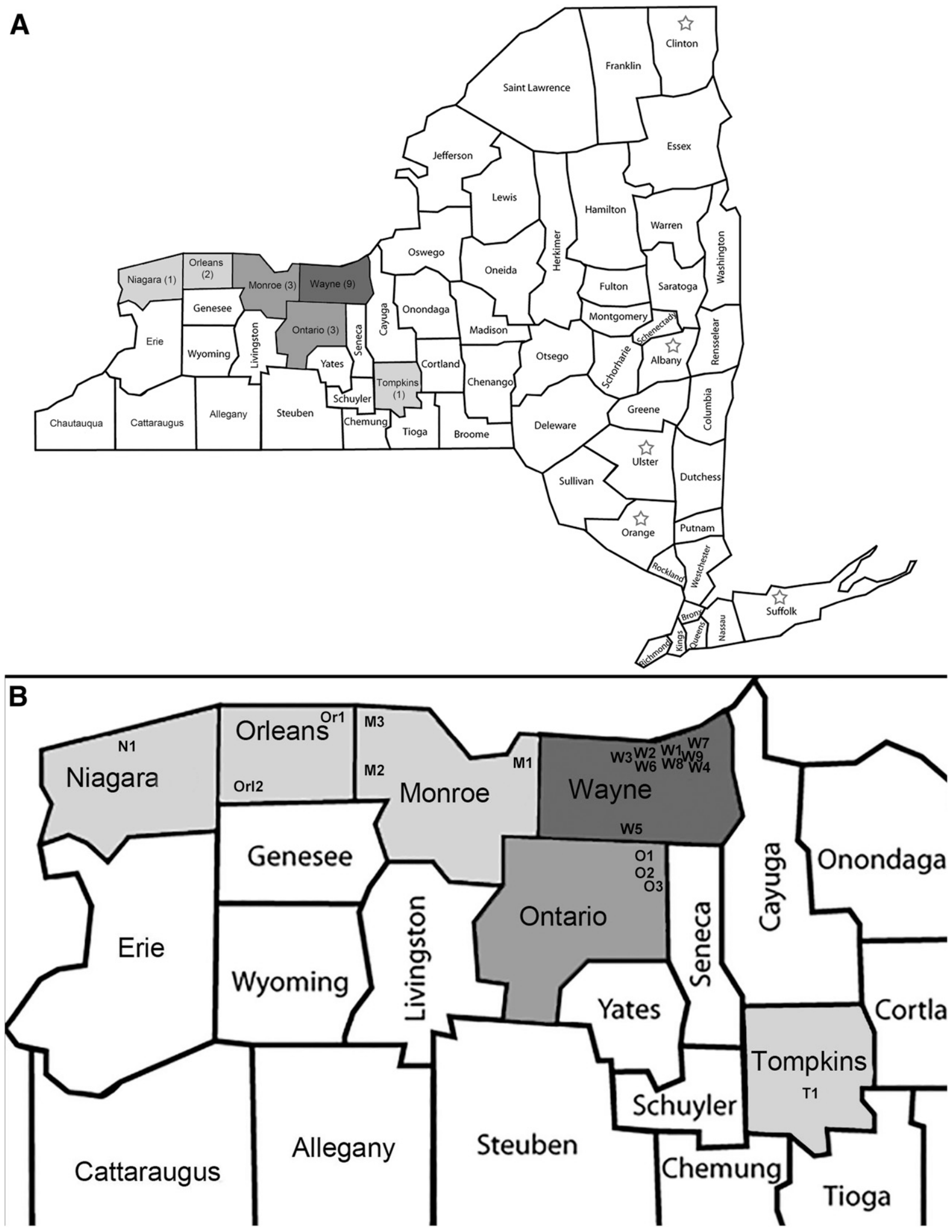

Fig. 1. New York State counties with orchards from which streptomycin-resistant (SmR) isolates of Erwinia amylovora were identified in 2011 to 2014 . A, Counties with 7 or more, 3 to 9 , or 1 to 2 orchards with SmR E. amylovora are shown in dark gray, medium gray, or light gray, respectively. Counties with star symbols had orchards with fire blight outbreaks and were surveyed but did not have SmR E. amylovora. B, Close-up of the five counties displaying the approximate location of the orchard designated by a letter for the county and numerical identifier. 
Russo et al. (2008). Indeed, direct reports to the authors from producers in 2011 suggest that others may have participated in the acquisition of such trees in 2002.

Interestingly, isolates 436 and 439, collected from the same orchard, had a slightly larger band for the pEA29 PCR amplicon with primer AJ75 and AJ76 (data not shown). Upon sequencing the product along with one of typical amplicon size, the pEA29 sequence revealed a variant, which was identical to isolate Ea356 (GenBank accession HF560643) isolated from Cotoneaster from Germany in 1979 (Zhao 2014). Although the presence of the $\operatorname{str} A / \operatorname{str} B$ gene pair in Tn5393 on pEA29 is believed to have a Michigan origin (McGhee et al. 2011; Russo et al. 2008), the presence of Tn5393 on a sequence variant of pEA29 from Europe suggests the possibility of another transposition. Such a discovery warrants further investigation to better determine the origin and movement of these 32 isolates.

Although the $32 \mathrm{SmR}$ E. amylovora isolates from this study containing the $s t r A / s t r B$ gene pair in the Tn5393 transposon on pEA29 are consistent with a Michigan or western New York origin, the two isolates with the K43R rpsL mutation from this study may suggest additional introductions or spontaneous development of resistance within New York orchards. E. amylovora isolates with the K43R rpsL mutation are most commonly found in California and Washington (Chiou and Jones 1991; Loper et al. 1991; Moller et al. 1981; Schroth et al. 1979;). Although isolates with the K43R $r p s L$ have been found in apple production operations in the eastern United States, they are rarely recovered (McManus et al. 2002). Apple production operations in western New York do order trees from nurseries in Washington State, but the trees from which isolates 306b and $189 \mathrm{a}$ were isolated were not obtained from the western United States and could represent one of these rare recoveries. The owners of the orchards from which these isolates were recovered reported fairly standard streptomycin use practices to the authors. Hence, the origin of isolates with the K43R rpsL mutation is still perplexing.

Given the possibility of multiple introductions and the presence of different resistant determinants, a more in-depth genetic analysis should be conducted to determine the origin of New York isolates and to investigate the movement of isolates throughout the state. Despite the information presented in this study, there is inherent difficulty in comparing these current isolates arising from the extremely limited diversity in the genome of E. amylovora (Sebaihia et al. 2010; Smits et al. 2010). Traditional diversity studies involving techniques such as random amplified polymorphic DNA, pulse-field gel electrophoresis, variable number of tandem repeats analyses, and ribotyping have shown difficulties in distinguishing strains (Jock et al. 2002; Kim and Geider 1999; McGhee and Sundin 2012; Momol et al. 1997). To investigate movement of isolates on a local and regional scale, a method that allows a high degree of differentiation must be employed. Clustered

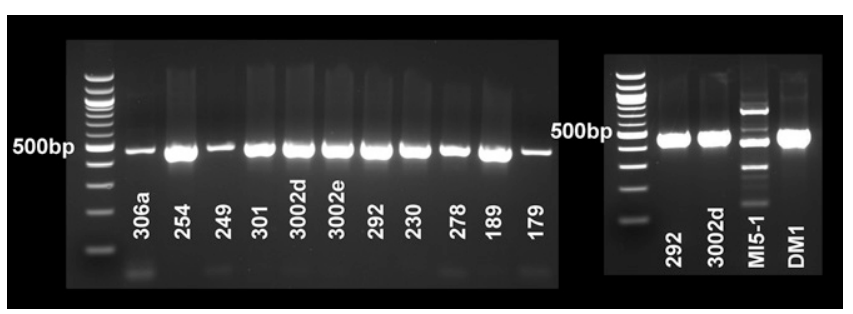

Fig. 2. Amplification of the Tn5393 insertion site in pEA29 at nucleotide position 17,527 in streptomycin-resistant (SmR) Erwinia amylovora from western New York using primers AJ507 and AJ339 from McGhee et al. (2011). Shown are agarose gels with the expected the 397-bp amplicon for the AJ507 and AJ339 primer pair spanning the $3^{\prime}$ end of Tn5393 at nucleotide position 17,527 to nucleotide position 17,922 in pEA29. Both gels have Quick-Load 100-bp DNA Ladder (New England Bio-Labs) to denote amplicon size. Lanes in the gel on the left are loaded with amplicons of SmR E. amylovora isolates collected from western New York in 2011 and 2012, while lanes in the right gel are loaded with amplicons of SmR E. amylovora isolates collected from western New York in 2012 and the two SmR-positive control isolates DM1 and MI5-1 (McGhee et al. 2011). Isolate MI5-1 has a Tn5393 insertion at position 1,515 on pEA29, and does not make the expected amplicon for primers AJ507 and AJ339. regularly interspaced short palindromic repeats (CRISPR) spacer analysis has recently been of interest in exploring strain diversity and tracking in several human-pathogenic bacteria, including Salmonella enterica, Escherichia coli, and Yersinia pestis (Almendros et al. 2014; Barros et al. 2014; Shariat et al. 2013). This method has also been used to explore diversity in Erwinia amylovora and was hypothesized to allow differentiation of isolates on a regional scale (McGhee and Sundin 2012). We are currently constructing CRISPR spacer profiles for New York SmR and $\mathrm{SmS} E$. amylovora isolates to investigate diversity and strain tracking.

In summary, streptomycin resistance is an emerging threat to the New York apple industry. A single isolated event in 2002 has become a greater issue over the past decade. Currently, $\mathrm{SmR}$ E. amylovora isolates are present throughout three of the six major apple-growing counties of New York. Although kasugamycin presents a viable antibiotic alternative to streptomycin for control of fire blight, it does not offer the same cost effectiveness. Hence, streptomycin is still widely used and resistance to streptomycin still poses a serious threat to the New York apple industry. To make matters worse, the most popular and highestvalue apple cultivars in the state are highly susceptible to E. amylovora. It is imperative that we continue to improve our understanding of this new threat in order to generate appropriate responses to mitigate the spread of streptomycin resistance in New York and prevent further spread of SmR E. amylovora to additional apple-growing regions of the United States.

\section{Acknowledgments}

This research was supported, in part, by funding from state, federal, and institutional funds appropriated to the New York State Agricultural Experiment Station. This research was also supported by funding from New York State IPM, New York State Department of Agriculture \& Markets-Specialty Crop Block Grant Program, and the Apple Research and Development Program.

\section{Literature Cited}

Almendros, C., Mojica, F. J. M., Díez-Villaseñor, C., Guzmán, N. M., and GarcíaMartínez, J. 2014. CRISPR-Cas functional module exchange in Escherichia coli. mBio 5:e0767-13.

Barros, M. P. S., França, C. T., Lins, R. H. F. B., Santos, M. D. V., Silva, E. J., Oliveira, M. B. M., Silveira-Filho, V. M., Rezende, A. M., Balbino, V. Q., and Leal-Balbino, T. C. 2014. Dynamics of CRISPR loci in microevolutionary process of Yersinia pestis strains. Online publication. PLoS ONE. doi:10.1371/journal. pone. 0108353

Beer, S. V., and Norelli, J. L. 1976. Streptomycin resistant Erwinia amylovora not found in western New York pear and apple orchards. Plant Dis. Rep. 60: 624-626.

Beer, S. V., and Norelli, J. L. 1977. Fire blight epidemiology: Factors affecting release of Erwinia amylovora by cankers. Phytopathology 67:1119-1125.

Bereswill, S., Pahl, A., Bellemann, P., Zeller, W., and Geider, K. 1992. Sensitive and species-specific detection of Erwinia amylovora by polymerase chain reaction analysis. Appl. Environ. Microbiol. 58:3522-3526.

Bertani, G. 1952. Studies on lysogenesis. I. The mode of phage liberation by lysogenic Escherichia coli. J. Bacteriol. 62:293-300.

Billing, E., Crosse, J. E., and Garrett, C. U. 1960. Laboratory diagnosis of fire blight and bacterial blossom blight of pear. Plant Pathol. 9:19-25.

Bonn, W. G., and van der Zwet, T. 2000. Breeding for resistance to fire blight Pages 253-273 in: Fire Blight: The Disease and Its Causative Agent. J. L. Vanneste, ed. CAB International, Wallingford, UK.

Burr, T. J., Norelli, J. L., Katz, B., Wilcox, W. F., and Hoying, S. A. 1988. Streptomycin resistance of Pseudomonas syringae pv. papulans in apple orchards and its association with a conjugative plasmid. Phytopathology 78:410-413.

Burr, T. J., Norelli, J. L., Reid, C. L., Capron, L. K., Nelson, L. S., Aldwinckle, H. S., and Wilcox, W. F. 1993. Streptomycin resistant bacteria associated with fire blight infections. Plant Dis. 77:63-66.

Chiou, C. S., and Jones, A. L. 1993. Nucleotide-sequence analysis of a transposon (Tn5393) carrying streptomycin resistance genes in Erwinia amylovora and other gram-negative bacteria. J. Bacteriol. 175:732-740.

Chiou, C. S., and Jones, A. L. 1991. The analysis of plasmid-mediated streptomycin resistance in Erwinia amylovora. Phytopathology 81:710-714.

Chiou, C. S., and Jones, A. L. 1995a. Molecular analysis of high-level streptomycin resistance in Erwinia amylovora. Phytopathology 85: 324-328.

Chiou, C. S., and Jones, A. L. 1995b. Expression and identification of the strA-strB gene pair from streptomycin-resistant Erwinia amylovora. Gene 152:47-51.

Cox, K. D., Aldwinckle, H. S., Villani, S. M., and Bekoscke, K. A. 2013 Evaluation of bactericide programs for the management of fire blight on 'Idared' apples in NY, 2012. Plant Dis. Manage. Rep. 7:PF001. http://www. plantmanagementnetwork.org/pub/trial/pdmr/volume7/abstracts/pf001.asp

Coyier, D. L., and Covey, R. P. 1975. Tolerance of Erwinia amylovora to streptomycin sulfate in Oregon and Washington. Plant Dis. Rep. 59:849-852. 
Crosse, J. E., and Goodman, R. N. 1973. A selective medium for and a definitive colony characteristic of Erwinia amylovora. Phytopathology 63:1425-1426.

Jamar, L., and Lateur, M. 2007. Strategies to reduce copper use in organic apple production. Acta Hortic. 737:113-120.

Jock, S., Donat, V., Lopez, M. M., Bazzi, C., and Geider, K. 2002. Following spread of fire blight in western, central, and southern Europe by molecular differentiation of Erwinia amylovora strains with PFGE analysis. Environ. Microbiol. 4:106-114.

Johnson, K. B., Sawyer, T. L., Stockwell, V. O., and Temple, T. N. 2009. Implications of pathogenesis by Erwinia amylovora on rosaceous stigmas to biological control of fire blight. Phytopathology 99:128-138.

Kim, W. S., and Geider, K. 1999. Analysis of variable short-sequence DNA repeats on the $29 \mathrm{~kb}$ plasmid of Erwinia amylovora strains. Eur. J. Plant Pathol. 105:703-713.

Loper, J. E., Henkels, M. D., Roberts, R. G., Grove, G. G., Willett, M. J., and Smith, T. J. 1991. Evaluation of streptomycin, oxytetracycline, and copper resistance of Erwinia amylovora isolated from pear orchards in Washington State. Plant Dis. 75:287-290.

McGhee, G. C., Guasco, J., Bellomo, L. M., Blumer-Schuette, S. E., Shane, W. W., Irish-Brown, A., and Sundin, G. W. 2011. Genetic analysis of streptomycinresistant (SmR) strains of Erwinia amylovora suggests that dissemination of two genotypes is responsible for the current distribution of SmR $E$. amylovora in Michigan. Phytopathology 101:182-191.

McGhee, G. C., and Jones, A. L. 2000. Complete nucleotide sequence of ubiquitous plasmid pEA29 from Erwinia amylovora strain Ea88: Gene organization and intraspecies variation. Appl. Environ. Microbiol. 66:4897-4907.

McGhee, G. C., and Sundin, G. W. 2011. Evaluation of kasugamycin for fire blight management, effect on nontarget bacteria, and assessment of kasugamycin resistance potential in Erwinia amylovora. Phytopathology 101:192-204.

McGhee, G. C., and Sundin, G. W. 2012. Erwinia amylovora CRISPR elements provide new tools for evaluating strain diversity and for microbial source tracking. Online publication. PLoS One. doi:10.1371/journal.pone.0041706

McManus, P. S., and Jones, A. L. 1994. Epidemiology and genetic analysis of streptomycin resistant Erwinia amylovora from Michigan and evaluation of oxytetracycline for control. Phytopathology 84:627-633.

McManus, P. S., and Jones, A. L. 1995. Detection of Erwinia amylovora by nested PCR and PCR-dot-blot and reverse-blot hybridizations. Phytopathology 85:618-623.

McManus, P. S., Stockwell, V. O., Sundin, G. W., and Jones, A. L. 2002. Antibiotic use in plant agriculture. Annu. Rev. Phytopathol. 40:443-465.

Miller, T. D., and Schroth, M. N. 1972. Monitoring the epiphytic population of Erwinia amylovora on pear with a selective medium. Phytopathology 62:1175-1182.

Moller, W., Schroth, M. N., and Thompson, S. V. 1981. The scenario of fire blight and streptomycin resistance. Plant Dis. 65:563-568.

Momol, M. T., Momol, E. A., Lamboy, W. F., Norelli, J. L., Beer, S. V., and Aldwinckle, H. S. 1997. Characterization of Erwinia amylovora isolates using random amplified polymorphic DNA fragments (RAPDs). J. Appl. Microbiol. 82:389-398.

Montag, J., Schreiber, L., and Schönherr, J. 2006. An in vitro study of the nature of protective activities of copper sulphate, copper hydroxide and copper oxide against conidia of Venturia inaequalis. J. Phytopathol. 154:474-481.

Norelli, J. L., Aldwinckle, H. S., and Beer, S. V. 1984. Differential host x pathogen interactions among cultivars of apple and isolates of Erwinia amylovora. Phytopathology 74:136-139.

Pal, K. K., and McSpadden Gardener, B. 2006. Biological control of plant pathogens. Online publication. Plant Health Instruct. doi:10.1094/PHI-A-2006-1117-02
Palmer, E. L., Teviotdale, B. L., and Jones, A. L. 1997. A relative of the broad host range plasmid RSF1010 detected in Erwinia amylovora. Appl. Environ. Microbiol. 63:4604-4607.

Robinson, T. L. 2008a. The evolution towards more competitive apple orchard systems in the USA. Acta Hortic. 772:491-500.

Robinson, T. L. 2008b. Crop load management of new high-density apple orchards. N.Y. Fruit Q. 16:3-7.

Robinson, T. L., Hoying, S. A., Miranda-Sazo, M., DeMarree, A., and Dominguez, L. 2013. A vision for apple orchard systems of the future. N.Y. Fruit Q. 21:11-17.

Rosen, H. R. 1936. Mode of penetration and progressive invasion of fire blight bacteria into apple and pear blossoms. Ark. Agric. Exp. Stn. Bull. 311. New York Agricultural Experiment Station, Geneva, NY.

Russo, N. L., and Aldwinckle, H. S. 2009. Fire blight and streptomycin: The reality of resistance. N.Y. Fruit Q. 17:17-19.

Russo, N. L., Burr, T. J., Breth, D. I., and Aldwinckle, H. S. 2008. Isolation of streptomycin-resistant isolates of Erwinia amylovora in New York. Plant Dis. 92:714-718.

Schroth, M. N., Thomson, S. V., and Moller, W. J. 1979. Streptomycin resistance in Erwinia amylovora. Phytopathology 69:565-568.

Sebaihia, M., Bocsancy, A. M., Biehl, B. S., Quail, M. A., and Perna, N. T. 2010 Complete genome sequence of the plant pathogen Erwinia amylovora strain ATCC 49946. J. Bacteriol. 192:2020-2021.

Shariat, N., Sandt, C. H., DiMarzio, M. J., Barrangou, R., and Dudley, E. G. 2013 CRISPR-MVLST subtyping of Salmonella enterica subsp. enterica serovars Typhimurium and Heidelberg and application in identifying outbreak isolates. BMC Microbiol. 13:254-271.

Smits, T. H. M., Rezzonico, F., Kamber, T., Blom, J., and Goesmann, A. 2010 Complete genome sequence of the fire blight pathogen Erwinia amylovora CFBP 1430 and comparison to other Erwinia spp. Mol. Plant-Microbe Interact. 23:384-393.

Stockwell, V. O., Temple, T. N., Loper, J. E., and Johnson, K. B. 2008 Integrated control of fire blight with antagonists and oxytetracycline. Acta Hortic. 793:383-390.

Sundin, G. W. 2014. Fire Blight. Pages 87-89 in: Compendium of Apple and Pear Diseases and Pests, 2nd ed. T. B. Sutton, H. S. Aldwinckle, A. M. Agnello, and J. F. Walgenbach, eds. American Phytopathological Society, St. Paul, MN.

Sundin, G. W., Werner, N. A., Yoder, K. S., and Aldwinckle, H. S. 2009. Field evaluation of biological control of fire blight in the eastern United States. Plant Dis. 93:386-394.

van der Zwet, T. 1969. Study of fire blight cankers and associated bacteria in pear. Phytopathology 59:607-613.

van der Zwet, T., Orolaza-Halbrendt, N., and Zeller, W. 2012. Fire Blight History, Biology, and Management. American Phytopathological Society, St. Paul, MN.

Vanneste, J. L. ed. 2000. Fire Blight: The Disease and Its Causative Agent, Erwinia amylovora. CABI Publishing, Oxon, UK.

Wael, L., Greef, M., and Laere, O. 1990. The honeybee as a possible vector of Erwinia amylovora (Burr.) Winslow et al. Acta Hortic. 273:107-114.

Yoder, K. S., Cochran, A. E., Royston, W. S., and Kilmer, S. W. 2012. Suppression of fire blight blossom blight by experimental and registered compounds on Idared apple, 2011. Online publication. Plant Dis. Manage. Rep. 6:PF031. http://www. plantmanagementnetwork.org/pub/trial/pdmr/volume6/abstracts/pf031.asp

Zhao, Y. 2014. Genomics of Erwinia amylovora and related Erwinia species associated with pome fruit trees. Pages 1-36 in: Genomics of Plant Associated Bacteria. D. C. Gross, A. Lichens-Park, and C. Kole, eds. Springer, Berlin, Heidelberg. 